\title{
SEJARAH TRANSFORMASI UANG DALAM ISLAM
}

\author{
Ressi Susanti \\ Pascasarjana Raden Intan Lampung
}

\begin{abstract}
Abstrak
Artikel ini ditulis untuk memberikan gambaran tentang sejarah uang dalam Islam. Guna memperoleh data yang dimaksud, penulis melakukan kajian kepustakaan. Sistem Ekonomi Islam berbeda dengan sistem ekonomi kapitalisme, sosialisme, ekonomi campuran, komunisme dan sistem ekonomi tradisional. Salah satu perbedaannya adalah pandangan tentang fisik uang. Fisik uang dalam sejarah Islam bertransformasi sesuai keinginan para pemimpin Islam yang bekuasa, dari mulai emas, perak, hingga uang kertas. Penjabaran tentang uang pada dimensi sejarah menjadi sangat penting karena munculnya geliat komunitas uang dirham saat ini, di mana kuasa uang kertas sudah sangat menggurita di seluruh dunia.
\end{abstract}

Kata Kunci: Sejarah Uang, Islam

\section{The History of Money Transformation in Islam}

This article is written to draw a picture of history of money in Islam. In order to gather data related, the writer prefers the review of related literature. The economic system in Islam is different from the capitalism, socialism, combined, communism and the traditional economic systems. One of the differences is the point of view toward the physical money. The physical money in the history of Islam transformed according to the ruling Islamic leader, ranging from muali of gold, silver, up to paper. The description of money in the historical dimension is important due to the twists of dirham community recently, when the paper money powerfully spread around the world.

Keywords: History of Money, Islam

\section{A. Pendahuluan}

Sebelum dikenal sistem moneter seperti yang berlaku dewasa ini, pernah berkembang sebelumnya perekonomian sistem barter yang dikenal dengan silent trade. ${ }^{1}$ Dalam perekonomian barter ini transaksinya dilakukan dengan cara mempertukarkan barang

\footnotetext{
Insukindro, Ekonomi Uang dan Bank: Teori dan Pengalaman di Indonesia, (Yogyakarta: BPFE, 1997), h. 2
} 
dengan barang. Perekonomian dengan sistem barter ini terjadi pada waktu itu belum dikenal sama sekali alat tukar yang disebut uang atau alat yang berfungsi sebagai alat pembayaran.

Fungsi uang ini amat beragam dan amat dibutuhkan dalam perekonomian, perdagangan maupun perbankan. Dalam dunia perbankan misalnya perbankan yang mempunyai tiga fungsi utama sebagai menerima simpanan uang, meminjamkan uang dan memberikan jasa memerlukan mata uang yang likuiditas dan kenetralan yang tinggi. ${ }^{2}$

Dewasa ini, dunia perbankan dalam perkembangannya telah mengalami perubahan yang sangat pesat, di mana uang menjadi objek dari perbankan telah mengalami perubahan yang lebih modern. Peranan uang dalam perekonomian antara lain dapat meningkatkan efisiensi baik bagi produsen, konsumen dan kegiatan ekonomi masyarakat pada umumnya.

Pada abad modern dan serba canggih ini, alat pembayaran yang efektif dan efisien sangatlah dibutuhkan pada transaksi jual beli, orang yang akan berbelanja tidak perlu lagi membawa uang dalam jumlah yang besar tetapi cukup dengan membawa selembar plastik berukuran kecil yang disebut kartu kredit (credit card). Transaksi mendunia tanpa uang tunai ini mulai menjadi tren sejak ditemukannya kartu kredit (credit card) atau kartu plastik (plastic card) dan kartu pintar (smart card). Seiring perkembangan ekonomi dan budaya masyarakat yang mulai meninggalkan kebiasaaan memakai uang tunai (cashless society). ${ }^{3}$

Atas dasar penjelasan tersebut lalu bagai-

Adiwarman Karim, Bank Dan Lembaga Keuangan Lainnya, (Jakarta: PT Grafindo Persada, 2005), h. 18

Redaksi Republika. DSN Desak BI Segera Izinkan Kartu Kredit Syariah: BI khawatir masyarakat konsumtif. Republika, 15 maret 2006. mana dengan eksistensi dan perkembangan sistem yang dianut dunia Islam. Dunia Islam saat ini amat dipengaruhi oleh sistem baru yang mengalami perkembangannya sangat signifikan, dinamai dan dikenal dengan sistem ekonomi Islam. Sesuai namanya, sistem ekonomi Islam ini muncul di antara kegagalan sistem ekonomi yang dikembangkan Barat dan adanya rasa haus kaum muslim akan suatu sistem yang merupakan interpretasi dari ajaran yang mereka anut, sehingga sistem ini berkembang begitu pesatnya. Kajian dalam ekonomi Islam tersebut menjadi semakin unik ketika harus menelaah lebih jauh sisi sejarah lahirnya uang di dalam Islam sehingga mampu menganalisa progresivitas transformasi uang dari masa nabi hingga saat ini.

\section{B. Definisi Uang dalam Islam}

Secara etimologi, definisi uang (nuqud) adalah ;

1. Al-Naqdu : yang baik dari dirham, dikatakan dirhamun naqdun yakni baik, dan ini adalah sifat. ${ }^{4}$

2. Al-Naqdu : Tunai, lawan tunda, yakni memberikan bayaran segera. Dalam hadits Jabir disebutkan, "Naqadani atTsaman", yakni dia membayarku harga tunai. Kemudian digunakan barang yang sudah dibayarkan, termasuk penggunaan masdar (akar kata) terhadap isim maf'ul (menunjukkan objek). ${ }^{5}$

Kata Nuqud tidak terdapat di dalam alQuran maupun hadits Nabi saw, karena bangsa Arab umumnya tidak menggunakan kata nuqud untuk menunjukkan harga. Mereka menggunakan kata dinar untuk menunjukkan

Al-Zamakhsyary, Asas Al-Balaghah, (Beirut: Dar Shadir, 1979), h. 650

Al-Zubaidy, Taj Al-Arus, (Kuwait: Muassasah Kuwait, 1965), h. 230 
mata uangyang terbuat dari emas, kata dirham untuk menunjukkan alat tukar yang terbuat dari perak. Mereka juga menggunakan kata Wariq untuk menunjukkan dirham perak, kata 'Ain untuk menunjukkan dinar emas.

Sedang kata fulus (uang tembaga), adalah alat tukar tambahan yang digunakan untuk membeli barang-barang murah. Adapun pengertian dari dinar dan dirham adalah;

1. Dinar berasal dari bahasa Romawi, Denarius, yaitu nama untuk emas cetakan. ${ }^{6}$

2. Dirham berasal dari bahasa Yunani, Drachma, yaitu nama untuk perak cetakan. ${ }^{7}$

Kata dirham dan dinar terdapat dalam alQuran dan Hadits. Firman Allah swt:

1. Ali Imran ayat 75 ;

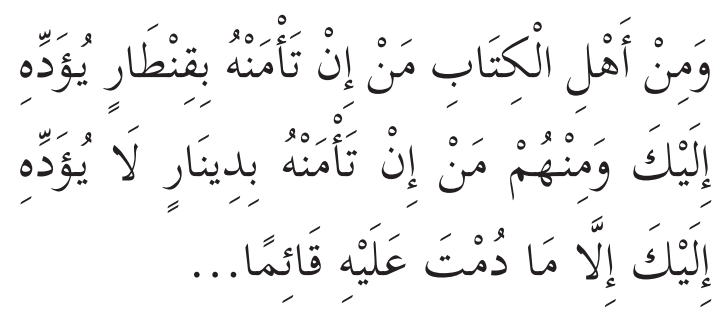

Artinya: "Di antara Ahli Kitab ada orang yang jika kamu mempercayakan kepadanya harta yang banyak, dikembalikannya kepadamu; dan di antara mereka ada orang yang jika kamu mempercayakan kepadanya satu dinar, tidak dikembalikannya padamu, kecuali jika kamu selalu menagihnya..."

2. Yusuf ayat 20 ;

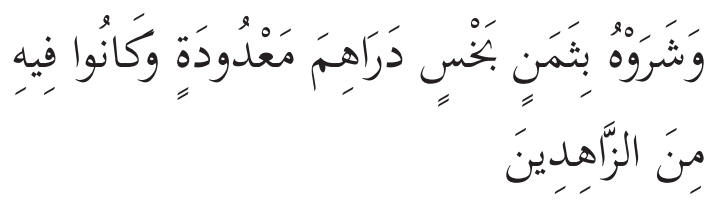

Anestas al-Kramly, al-Nuqud al-Arabiyah wa al-Islamiyah wa Ilmu al-Nammiyat, (t.t.: al-Markaz al-Islamy, 1987), h. 30

Ahmad, al-Misbah al-Munir fi Garib al-Syarh al-Kabir li al-Rafi'i, (Kairo: Al-Amiriah, 1926), h. 262

8 Departemen Agama RI, Al-Hikmah Al-Qur'an dan Terjemahannya, (Bandung: Diponegoro, 2006), h. 59
Artinya: "Dan mereka menjual Yusuf dengan harga yang murah, yaitu beberapa dirham saja, dan mereka merasa tidak tertarik hatinya kepada Yusuf."

Nabi Muhammad saw bersabda dalam hadits yang diriwayatkan oleh Utsman bin Affan: "Jangan kalian jual satu dinar dengan dua dinar, dan satu dirham dengan dua dirham." ${ }^{10}$ dan juga Nabi Muhammad saw bersabda dalam hadits yang diriwayatkan oleh Abu Sa'id al-Khudry : "Jangan kalian jual emas dengan emas, perak dengan perak kecuali sama nilai, ukuran dan timbangan."11

Secara terminologi, uang diartikan oleh al-Ghazali dan Ibn Khaldun sebagai apa yang digunakan manusia sebagai standar ukuran nilai harga, media transaksi pertukaran dan media simpanan, ${ }^{12}$ dengan penjelasan:

1. Uang sebagai ukuran harga

Abu Ubaid (w. 224 H) menyatakan bahwa dirham dan dinar adalah nilai harga sesuatu, sedangkan segala sesuatu tidak bisa menjadi nilai harga keduanya. ${ }^{13}$ Imam Ghazali (w. 505 H) menegaskan bahwa Allah menciptakan dinar dan dirham sebagai hakim penengah diantara seluruh harta agar seluruh harta bisa diukur dengan keduanya. Dikatakan, unta ini menyamai 100 dinar, sekian ukuran minyak za'faran ini menyamai 100. Keduanya kira-kira sama dengan satu ukuran, maka keduanya bernilai sama.

Ibn Rusyd (w. 595 H) menyatakan

Ibid. h. 237

10 CD Al-Bayan, Muslim, Kitab Al-Mutsaqat, Bab Al-Riba, Hadits no. 2967

11 Ibid., Hadits no. 2966

12 Adiwarman A Karim, Ekonomi Makro Islami, (Jakarta: Rajagrafindo Persada, 2007), h. 80

13 Abu Ubaid al-Qasim bin Salam, al-Amwal, Tahqiq Muhammad Khalil Harras, (Beirut: Dar al-Fikr, 1988), h 512 
bahwa, ketika seseorang susah menemukan nilai persamaan antara barang-barang yang berbeda, jadikan dinar dan dirham untuk mengukurnya. Apabila seseorang menjual kuda dengan beberapa baju, nilai harga kuda itu terhadap beberaba kuda adalah nilai harga baju itu terhadap beberapa baju. Maka jika kuda itu bernilai 50, tentunya baju-baju itu juga harus bernilai 50 .

2. Uang sebagai media transaksi

Uang menjadi media transaksi yang sah yang harus diterima oleh siapa pun bila ia ditetapkan oleh negara. Inilah perbedaan uang dengan media transaksi lain seperti cek. Berlaku juga cek sebagai alat pembayaran karena penjual dan pembeli sepakat menerima cek sebagai alat bayar. Begitu pula dengan kartu debet, kartu kredit dan alat bayar lainnya. Pihak yang dibayar dapat saja menolak penggunaan cek atau kartu kredit sebagai alat bayar sedangkan uang berlaku sebagai alat pembayaran karena negara mensahkannya.

UmarbinKhatabrapenahmenjelaskan bahwa saat ia ingin menjadikan uang dari kulit unta, lalu ada yang memberi masukan, bahwa jika itu dilakukan maka unta akan punah, lalu ia membatalkan keinginannya tersebut. Sebaliknya emas dan perak tidak serta merta menjadi uang bila tidak ada stempel (sakkah) negara.

Imam Nawawi menegaskan bahwa makruh hukumnya bagi rakyat biasa mencetak sendiri dirham dan dinar, sekalipun dari bahan yang murni, sebab pembuatan tersebut adalah wewenang pemerintah. Kemudian apabila dirham tercampur maka dapat diketahui kadar campurannya, dengan demikian boleh menggunakannya baik dengan kebenda- annya maupun dengan nilainya.

Adapun jika kadar campuran tersebut tidak diketahui, maka di sini ada dua pendapat. Pendapat yang paling sahih mengatakan hukumnya boleh. Sebab, yang dimaksudkan adalah lakunya di pasaran. Campuran dari tembaga yang terdapat pada dirham tersebut tidak mempengaruhi, sebagaimana halnya adonan.

3. Uang sebagai media penyimpanan nilai Al-Ghazali pernah menjelaskan bahwa karena disebabkan oleh jual beli, muncul kebutuhan terhadap dua mata uang. Seseorang yang ingin membeli makanan dengan baju, dari mana dia mengetahui ukuran makanan dari nilai baju tersebut. Jual beli terjadi pada jenis barang yang berbeda-beda seperti dijual baju dengan makanan dan hewan dengan baju.

Barang-barang ini tidak sama, maka diperlukan "hakim yang adil" sebagai penengah antara kedua orang yang ingin bertransaksi dan berbuat adil satu dengan yang lain. Keadilan itu dituntut dari jenis harta. Kemudian diperlukan jenis harta yang bertahan lama karena kebutuhan yang terus-menerus. Jenis harta yang paling bertahan lama adalah barang tambang. Maka dibuatlah uang dari emas, perak, dan logam.

Ibnu khaldun juga mengisyaratkan uang sebagai alat simpanan. Ia menyatakan, kemudian Allah Ta'ala menciptakan dari dua barang tambang, emas dan perak sebagai nilai untuk setiap harta. Dua jenis ini merupakan simpanan dan perolehan orang-orang di dunia kebanyakannya.

Dari ketiga fungsi tersebut jelaslah bahwa yang terpenting adalah stabilitas uang, bukan bentuk uang itu sendiri, 
uang dinar yang terbuat dari emas dan diterbitkan oleh raja Dinarius dari Kerajaan Romawi memenuhi kriteria uang yang nilainya stabil. Begitu pula uang dirham yang terbuat dari perak dan diterbitkan oleh Ratu dari Kerajaan Sasanid Persia juga memenuhi kriteria uang stabil. Sehingga, meskipun dinar dan dirham diterbitkan oleh bukan negara Islam, keduanya dipergunakan di zaman Rasulullah saw.

\section{Sejarah Pencetakan Uang dalam Islam}

Ulasan tentang uang dalam sistem pemerintahan Islam sangatlah panjang dan terperinci, karena itu penulis mencoba menyimpulkan dalam poin-poin berikut.

\section{Pada Masa Nabi Muhammad saw}

Bangsa Arab di Hijaz pada masa Jahiliyah tidak memiliki mata uang tersendiri. Mereka menggunakan mata uangyang mereka peroleh berupa Dinar emas Hercules, Byziantum dan Dirham perak Dinasti Sasanid dari Iraq, dan sebagian mata uang bangsa Himyar, Yaman.

Penduduk Makkah tidak memperjualbelikannya kecuali sebagai emas yang tidak ditempa dan tidak menerimanya kecuali dalam ukuran timbangan. Mereka tidak menerima dalam jumlah bilangan. Hal itu disebabkan beragamnya bentuk dirham dan ukurannya dan munculnya penipuan pada mata uang mereka seperti nilai tertera yang melebihi dari nilai yang sebenarnya.

Ketika Nabi saw diutus sebagai nabi dan rasul, beliau menetapkan apa yang sudah menjadi tradisi penduduk Makkah,, ${ }^{14}$ dan beliau memerintahkan penduduk Madinah untuk mengikuti ukuran timbangan

14 Al-Maqrizi, Syudzur al-'Uqud fi Dzikir al-Nuqud, tahqiq Muhammad Bahrul Ulum, (Beirut: Dar al-Zahra, 1988), Cet. 6, h. 55 penduduk Makkah ketika itu mereka berinteraksi ekonomi menggunakan dirham dalam jumlah bilangan bukan ukuran timbangan. Beliau bersabda :

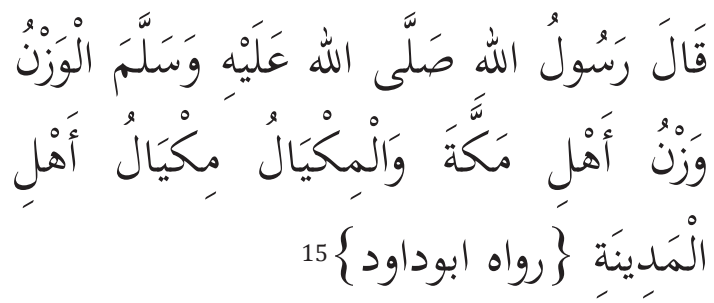

"Timbangan adalah timbangan penduduk Makkah, sedang takaran adalah takaran penduduk Madinah."

Sebab munculnya perintah itu adalah perbedaan ukuran dirham Persia karena terdapat tiga bentuk cetakan uang, yakni:

a. ada yang ukurannya 20 qirath (karat),

b. ada yang ukurannya 12 karat,

c. ada yang ukurannya 10 karat. $^{16}$

Lalu ditetapkanlah dalam dirham Islam menjadi 14 karat dengan mengambil sepertiga dari semua dirham Persia yang ada. $20+12+10=42 / 3=14$, sama dengan 6 daniq (bahasa Yunani yakni dua butir uir-uir belalang). Setiap daniq seukuran 7 mitsqal (mitsqal dalam ukuran sekarang adalah gram). Demikian Nabi saw juga mempunyai peranan dalam masalah keuangan, yaitu menentukan ukuran timbangannya. Bersama itu, mereka yang menulis tentang uang dari pandangan Islam tidak menyinggung soal peranan ini, hanya saja Rasulullah saw tidak mengubah mata uang karena kesibukannya memperkuat tiang-tiang agama Islam di Jazirah Arab, karena itu sepanjang masa kenabian, kaum Muslim terus menggunakan mata uang asing dalam interaksi ekonomi mereka. ${ }^{17}$

\footnotetext{
15 CD Al-Bayan, Abu Daud, Kitab Al-Buyu', Bab Fi Qoul An-Nabi saw Al-Mikyal Mikyal Ahli Madinah, Hadits no. 2699

16 Ibnu Khaldun, Al-Muqaddimah, (Beirut: Dar Al-Fikr, 1988), h. 323

17 Hasan Ali Al-Hallaq, Ta'rib Al-Nuqud wa Al-Dawawin fi Al-'Ashri
} 


\section{Pada Masa Khulafa' Ar-Rasyidin}

a. Masa Khalifah Abu Bakar ash-Shiddiq Masa pemerintahan Khalifah Abu Bakar ash-Shiddiq keadaan bentuk mata uang dinar masih sama dengan masa Nabi Muhammad saw. Hal ini disebabkan karena masa pemerintahan Khalifah Abu Bakar ash-Shiddiq reatif pendek dan banyak juga perkara yang harus ditangani. Perkara-perkara tersebut antara lain adalah memerangi orang murtad dan orang-orang yang enggan untuk membayar zakat.

b. Masa Khalifah Umar bin Khathab

Pada tahun $18 \mathrm{H}$, yakni pada masa kekhalifahan Umar bin Khathab, dicetak dirham Islam. Pada masa tersebut perkembangan uang mulai dirasakan, namun lebih banyak berkaitan dengan uang dirham (uang perak). Pada awalnya dirham hanya berupa fulus perunggu yang dicetak dengan menggunakan aksara Arab di setiap sisinya. Setelah itu, barulah Khalifah Umar ra melakukan halhal penting dalam masalah uang.

1) Percetakan uang dirham dengan ciri-ciri keislaman. Bentuk uang dirham Islam pertama ini hampir sama dengan dirham Persia. Hanya saja terdapat tulisan tambahan seperti "Alhamdulillah", "Muhammad Rasulullah", "Laa ilaha illa Allah wahdahu" dan juga nama khalifah "Umar". Sebab dicetaknya uang dirham ini karena pada masa itu aktivitas perdagangan berkembang semakin luas seiring dengan semakin meluasnya wilayah Islam.

2) Ditetapkannya standar kadar dirham dan dikaitkannya standar tersebut

Al-Umawi, (Libanon: Dar al-Kutub Al-Lubnani, 1986), h. 22 dengan kaitan pada masa itu beredar berbagai jenis dirham dengan takaran yang bereda-beda pula. Ada yang menyebutnya dengan takaran dawaniq, misalnya dirham Al-Baghaly sebesar 8 dawaniq, dirham al-Thabary sebesar 4 dawaniq. Ada pula yang menggunakan istilah mistqal yang artinya 1 dirham adalah 1 mistqal. Takaran mistqal pun berbeda-beda, ada yang menyatakan 20 qirad, 12 qirad, 10 qirad, dan lain-lain.

Atas segala perbedaan tersebut, Khalifah Umar membuat kebijakan dengan melihat pada apa yang berlaku di tengah masyarakat baik takaran yang rendah maupun takaran yang tinggi. Sehingga Khalifah Umar menetapkan standar dirham yang dikaitkan dengan dinar, yaitu 1 dirham sama dengan $7 / 10$ dinar, atau setara dengan 2,97 gram dengan landasan standar dinar 4,25 gram emas. Standar inilah yang kemudian berlaku secara baku dalam landasan syar'i.

3) Ada usaha Khalifah Umar untuk membuat uang dengan bentuk lain, yaitu dengan menggunakan bahan dasar kulit hewan (kambing). Pemikiran ini terjadi karena Khalifah Umar menganggap bahwa uang kulit reatif lebih mudah untuk dibawa sehingga memudahkan untuk melakukan kegiatan transaksi. Hal tersebut dipicu dengan keadaan perekonomian yang semakin membaik seiring dengan meluasnya wilayah Islam. Namun hal ini diurungkan, karena banyaknya sahabat yang tidak menyetujui dengan pertimbangan bahwa bahan 
kulit tidak dapat dijadikan standar of value karena harga kulit berfluktuasi seiring dengan fluktuasi harga binatang itu sendiri, yang mengikuti harga perkembangan pasar. Selain itu, juga karena sifat dasar kulit sendiri yang mudah rusak sehingga tidak aman jika digunakan sebagai alat tukar yang sah.

Khalifah Umar pun menetapkan standar koin dinar dan dirham. Berat 7 dinar sama dengan 10 dirham. Standar dinar emas yakni memakai kadar emas 22 karat dengan berat 4,25 gram. Sedangkan dirham harus menggunakan perak murni seberat 3,0 gram. Keputusan ini telah ditetapkan pula dengan para ulama pada masa itu.

c. Masa Khalifah Utsman bin «Affan Pada masa ini perkembangan yang penting adalah dicetaknya uang dinar dan dirham baru dengan memodifikasi uang dinar Persia dan ditulis simbolsimbol Islam. Di mana di dalam uang dinar tersebut terdapat tulisan "Allahhu Akbar". Ada pula yang meriwayatkan bahwa dirham di masa ini di satu sisi bergambar Croeses ke II yang dipahat bersama dengan kota asalnya, dengan tanggal dan aksara Persia. Di batas koin juga terdapat kata-kata dalam aksara Kuffi, yang artinya "Rahmat, dengan asma Allah, dengan asma Tuhanku, bagi Allah, Muhammad". Sejauh ini dinar belum ada yang dicetak khusus sesuai dengan berinisial Islam saja.

d. Masa Khalifah Ali bin Abi Thalib

Ketika Ali bin Abi Thalib menjadi khalifah, beliau mencetak dirham mengikuti model Khalifah Utsman bin Affan dan menuliskan di lingkarannya salah satu kalimat Bismillah, Bismillah Rabbi, dan Rabiyallah dengan jenis tulisan Kufi. ${ }^{18}$

\section{Pada Masa Dinasti Umayyah}

Pencetakan uang pada masa Dinasti Umawiyah semenjak masa Muawiyah bin Abi Sofyan masih meneruskan model Sasanid dengan menambahkan beberapa kata tauhid seperti halnya pada masa Khulafaur Rasyidin. Pada masa Abdul Malik bin Marwan, setelah mengalahkan Abdullah bin Zubair dan Mush'ab bin Zubair, beliau menyatukan tempat percetakan. Pada tahun $76 \mathrm{H}$ beliau membuat mata uang Islam yang bernapaskan model Islam tersendiri, tidak ada lagi isyarat atau tanda Byzantium atau Persia. Dengan demikian, Abdul Malik bin Marwan adalah orang yang pertama kali mencetak dinar dan dirham dalam model Islam tersendiri.

Banyak silang pendapat yang menguraikan alasan apa yang menyebabkan Abdul Malik menempa Dinar dalam model Islam tersendiri itu. Ada yang mengatakan karena alasan-alasan keagamaan, karena dinar-dinar itu sebelumnya diukir dengan ungkapanungkapan trinitas. Ada juga yang mengatakan karena perselisihan yang terjadi antara Abdul Malik dengan kerajaan Romawi. Bagaimanapun juga, apa yang telah dilakukan oleh Abdul Malik mampu merealisasikan stabilitas politik dan ekonomi, mengurangi pemalsuan dan manipulasi terhadap mata uang. ${ }^{19}$

Pemberantasan pemalsuan dan pengetatan terus berlanjut pada masa Yazid bin Abdul Malik dan Hisyam bin Abdul Malik. Bahkan Hisyam pernah memeriksa dirham dan mengetahui ukurannya kurang satu butir. Beliau menghukum pembuatnya dengan

18 Nashir al-Sayyid Muhammad Al-Naqsyabandi, Al-Dirham AlIslami, Al-Madhrub 'Ala Al-Thiraz Al-Sasani, (Mesir: Dar Al-Kutub Al-'Ilmiyah, t.th.), h. 10

19 Abdul Mut'al Muhammad Al-Jabari, Ashalat Al-Dawawim AlNuqud Al-Arabiyah, (Kairo: Dar Al-Taufiq AL-Namudzajiyah, 1989), h. 76 
1000 cambuk, dan mereka berjumlah 100 orang sehingga beliau menghukum dalam tiap satu butir dengan 100.000 kali cambuk. Begitulah akhirnya Dinar masa Umawiyah terkenal halus, akurat, dan murni. Sebagai bukti kemajuan dalam perkembangan uang. ${ }^{20}$

\section{Pada Masa Abbasiyah dan Sesudahnya}

Pada masa Abbasiyah, pencetakan dinar masih melanjutkan cara Dinasti Umawiyah. Al-Saffah mencetak dinarnya yang pertama pada awal berdirinya Dinasti Abbasiyah tahun 132 H mengikuti model dinar Umawiyah dan tidak mengubah sedikitpun kecuali pada ukiran-ukiran.

Sedangkan dirham, pada awalnya ia kurangi satu butir kemudian dua butir. Pengurangan ukuran dirham terus berlanjut pada masa Abu Ja'far al-Manshur, dia mengurangi tiga butir hingga pada masa Musa al-Hadi kurangnya mencapai satu karat (qirath). Dinar pun tidak seperti adanya, pengurangan terjadi setelah itu. Namun begitu, nilainya dihitung seperti semula. Al-Maqrizy berkata: "Pada bulan Rajab tahun 191 H, dinar Hasyimiah mengalami pengurangan sebanyak setengah butir dan hal itu terus berlanjut sepanjang periode tapi masih berlaku seperti semula." ${ }^{21}$ Pada masa Dinasti Fathimiyah, dirham-dirham campuran sangat banyak menyebabkan harganya turun, sehingga pada masa al-Hakim bin Amrillah, harga dinar sama dengan 34 dirham, padahal perbandingan asli antara dinar dan dirham adalah $1: 10 .{ }^{22}$

Pada masa Shalahuddin al-Ayyubi Rahimahullah, bahan baku emas tidak cukup untuk pencetakan dinar disebabkan berbagai peperangan. Karena itu, mata uang utama

Ibnu Al-Atsir, Al-Kamil fi Al-Tarikh, (Beirut: Dar Shadir, 1982), Jil. 4, h. 417

21 Al-Maqrizi, op.cit., h. 70

22 Ibid., h. 80 adalah perak dan tidak juga murni, bahkan separuhnya adalah tembaga. Pencetakan uang dalam bentuk ini terus berlanjut di Mesir dan Syam (Syiria) sepanjang masa pemerintahan Bani Ayyub.

Pada masa pemerintahan Mamalik, pencetakan uang tembaga (fulus) tersebar luas. Bahkan pada masa pemerintahan raja al-Zhahir Barquq dan anaknya Farj, uang tembaga menjadi mata uang utama, dan pencetakan dirham dihentikan karena beberapa sebab, yakni:

a. Penjualan perak ke negara-negara Eropa.

b. Impor tembaga dari negara-negara Eropa yang semakin bertambah akibat dari peningkatan produksi pertambangan di sebagian besar wilayah Eropa.

c. Meningkatnya konsumsi perak untuk pembuatan pelana dan bejana. ${ }^{23}$

Namun uang tembaga tidak selamanya menjadi mata uang utama bahkan kembali kepada fungsinya yang pertama sebagai mata uang bantu. Pada masa Sultan Muayyad, uang logam digunakan untuk barang-barang murah. Sedangkan mata uang utama adalah dirham perak dan dinamakan Dirham Muayyad. ${ }^{24}$

Pada masa Dinasti Ottoman, sistem keuangan resmi Utsmaniyah tahun 955 H/1534 M, berdasarkan pada dua barang tambang, emas dan perak dengan perbandingan 1:15. Pada tahun 1839 M, pemerintah Utsmaniyah menerbitkan mata uang baru yang diberi nama Gaima bentuk kertas-kertas banknotel ganti imbangan saldo emas. Hanya nilainya terus merosot sehingga orang-orang tidak

\footnotetext{
23 A. Arthur, Al-Tarikh Al-Iqtishodi wa al-ijtima'iyah li syaraq alautsah fi al-'ushur al-wustha, (Damaskus: Dar Kutaibah, 1985), h. 389

24 Al-Maqrizi, op.cit., h. 84
} 
mempercayainya. ${ }^{25}$

\section{Tranformasi Menjadi Uang Kertas}

Pada tahun 1839 pemerintah Usmaniyah menerbitkan mata uang yang berbentuk kertas banknote dengan nama gaima, namun nilainya terus merosot sehingga rakyat tidak mempercayainya. Pada perang Dunia I tahun 1914, Turki seperti negara-negara lainnya memberlakukan uang kertas sebagai uang yang sah dan membatalkan berlakunya emas dan perak sebagai mata uang. Sejak itulah mulai diberlakukan uang kertas sebagai satusatunya mata uang di seluruh dunia. ${ }^{26}$

Uang yang berlaku pada zaman sekarang disebut dengan fiat money. Hal ini disebabkan karena kemampuan uang untuk berfungsi sebagai alat tukar dan memiliki daya beli tidak disebabkan karena uang tersebut dilatarbelakangi oleh emas. Pada zaman dahulu, uang dilatarbelakangi oleh emas karena mengikuti standar emas. Namun, hal ini telah ditinggalkan oleh perekonomian dunia pada tahun 1931 dan kemudian seluruh dunia telah meninggalkannya pada tahun 1976. Uang kertas sekarang sudah menjadi alat tukar karena telah ditetapkan oleh pemerintah bahwa uang kertas sudah menjadi standar alat tukar.

Umar bin Khathab berkata bahwa mata uang dapat dibuat dari benda apa saja sampai-sampai kulit unta. Ketika suatu benda tersebut sudah ditetapkan menjadi mata uang yang sah, maka barang tersebut sudah berubah fungsinya dari barang biasa menjadi alat tukar yang sah dengan segala fungsi dan turunannya. Jumhur ulama telah sepakat

25 Abdul Mun'im Al-Sayyid Ali, Al-Tathowar Al-Tarikhi li AlAnzhimah Al-Naqdiyah fi Al-Aqthor Al-'Arobiyah, (Beirut: Markaz Dirasat Al-Wihdah Al-'Arabiyah, 1993), h. 101

26 Rozalinda, Ekonomi Islam: Teori dan Aplikasinya pada Aktivitas Ekonomi, (Jakarta: Rajawali Pers: 2014), h. 2 bahwa illat, emas dan perak diharamkan pertukarannya kecuali serupa dengan serupa, sama dengan sama oleh Rasulullah saw adalah karena tsumuniyyah yaitu barang-barang tersebut menjadi alat tukar, penyimpanan nilai di mana semua barang ditimbang dan dinilai dengan nilainya. ${ }^{27}$

Saat uang kertas telah menjadi alat pembayaran yang sah, sekalipun tidak dilatarbelakangi oleh emas, maka kedudukannya dalam hukum sama dengan kedudukan emas dan perak yang pada waktu al-Quran diturunkan tengah menjadi alat pembayaran yang sah. Uang kerta juga diakui sebagai harta kekayaan yang harus dikeluarkan zakat daripadanya. Zakat pun sah dikeluarkan dalam bentuk uang kertas. Uang kertas juga dapat dipergunakan sebagai alat untuk membayar mahar.

Ada beberapa kelebihan penggunaan uang kertas dalam perekonomian modern ini, di antaranya mudah dibawa, biaya penerbitan lebih kecil daripada uanglogam, dapat dipecah dalam jumlah berapapun. Namun pemakaian uang kertas ini mempunyai kekurangan seperti tidak terjaminnya stabilitas nilai tukar seperti halnya uang emas dan perak yang mempunyai nilai tukar yang stabil. Di samping itu, jika terjadi percetakan uang kerta dalam jumlah yang berlebihan, akan menimbulkan inflasi, nilai uang turun harga barang naik.

\section{E. Kesimpulan}

Mata uang sudah ada sebelum Islam datang, dan pada masa Nabi Muhammad saw, ditetapkanlah dalam dirham Islam menjadi 14 karat dengan mengambil sepertiga dari

\footnotetext{
27 Nurul Huda, dkk, Ekonomi Makro Islam: Pendekatan Teoritis (Jakarta: Kencana, 2009), h. 92
} 
semua dirham Persia yang ada. Adapun pada masa kekhalifahan Umar bin Khathab sampai dengan Ali bin Abi Thalib radiallahu 'anhum, dicetak uang Islam dengan isi ukiran Islam.

Pada masa selanjutnya, yakni masa Bani Umayyah, Abdul Malik bin Marwan menjadi orang yang pertama kali mencetak dinar dan dirham dalam model seni Islam tersendiri. Adapun awal mula adanya pengganti dinar dan dirham menjadi uang kertas terjadi setelah pemerintahan bani Abbasiyah, yakni pada masa Dinasti Ottoman (Utsmaniyah) berkuasa di dalam pemerintahan Islam dunia.

\section{DAFTAR PUSTAKA}

Abdul Mut'al Muhammad Al-Jabari, Ashalat Al-Dawawim Al-Nuqud Al- 'Arabiyah, Dar Al-Taufiq AL-Namudzajiyah, Cairo, 1989.

Anestas al-Kramly, Al-Nuqud Al-'Arabiyah wa Al-Islamiyah wa Ilmu Al-Nammiyat, alMarkaz al-Islamy Li Thiba'ah wa al-Nasyr, t.tp, 1987.

Ahmad, Al-Misbah Al-Munir fi Garib Al-Syarh Al-Kabir li Al-Rafi'i, Al-Amiriah, C a i r o, 1926.

Al-Maqrizi, Syudzur Al-'Uqud fi Dzikir AlNuqud, tahqiq Muhammad Bahrul Ulum, Dar al-Zahra, Beirut, 1988.

A. Arthur, Al-Tarikh Al-Iqtishodi wa AlIjtima'iyah li Syaraq Al-Autsah fi Al'Ushur Al-Wustha, Dar Kutaibah, Damasik, 1985.
Abdul Mun'im Al-Sayyid Ali, Al-Tathowar AlTarikhi li Al-Anzhimah Al- Naqdiyah fi AlAqthor Al-Arobiyah, Markaz Dirasat AlWihdah Al- 'Arabiyah, Beirut, 1993.

Al-Zamakhsyary, Asas Al-Balaghah, Dar Shadir, Beirut, 1979.

Al-Zubaidy, Taj Al-'Arus, Muassasah Kuwait, Kuwait, 1965.

CD Al-Bayan

Departemen Agama RI, Al-Hikmah Al-Qur'an dan Terjemahannya, Diponegoro, Bandung, 2006.

Hasan Ali Al-Hallaq, Ta'rib Al-Nuqud wa AlDawawin fi Al-'Ashri Al-Umawi, Dar alKutub Al-Lubnani, Libanon, 1986.

Ibnu Al-Atsir, Al-Kamil fi Al-Tarikh, Dar Shadir, Beirut, 1982.

Ibnu Khaldun, Al-Muqaddimah, Dar Al-Fikr, Beirut, 1988.

Nashir Al-Sayyid Muhammad Al-Naqsyabandi, Al-Dirham Al-Islami, Al-Madhrub 'Ala Al-Thiraz Al-Sasani, Dar Al-Kutub Al'Ilmiyah, Mesir, t.th. 